\title{
CONTRIBUTION TO THE STRUCTURAL STUDY OF THE RHODIANI OPHIOLITES, VOURINOS MASSIF
}

\author{
A. PHOTIADES ${ }^{1}$ \& F. POMONI-PAPAIOANNOY ${ }^{2}$
}

\begin{abstract}
The Rhodiani area geologically is comprised of a sequence of Mesozoic and Tertiary thrust sheets, including the Jurassic ophiolite and sedimentary covers; they composed of an ultramafic unit overlain by an Albian to Cenomanian redeposited limestone cover, and at the top a volcanic unit that is overlain by neritic to pelagic Upper Jurassic to Upper Cretaceous age limestone and Upper Maastrichtian flysch deposits. These thrust sheets were emplaced over the Pelagonian platform. Therefore the Rhodiani "ophiolite" is not a single thrust unit, but it is an imbricated ophiolite tectonic structure resulting from a two-stage emplacement process; the ultramafic unit was overthrust on the melange of the Pelagonian platform during the initial emplacement (Jurassic) and the volcanic unit was re-thrust on the former during subsequent post-Eocene tectonic phase.
\end{abstract}

KEY WORDS: mapping; stratigraphy; structure; ophiolite; obduction; internal Hellenides; Vourinos; Rhodiani; Greece.

\section{INTRODUCTION}

The study area occupies the eastern slopes of the Vourinos massif, which represents the eastern boundaries of the Meso-Hellenic trough. Geotectonically it belongs to the Pelagonian domain.

The tectonic origin of the Vourinos ophiolite is controversial and two different emplacement models have been proposed for it: a) an easterly derived with emplacement verging to the Southwest onto the Pelagonian zone (Vergely, 1977; 1984), and b) of a westerly derivation from within the Pindos ocean (Naylor \& Harle, 1976; Smith et al., 1979; Mountrakis, 1984; Jones \& Robertson, 1991; Grivas et al., 1993).

The Rhodiani ophiolite massif lies in a distance of $3 \mathrm{~km}$ to the east of the Vourinos ophiolite complex (Fig.1). It trends from NW to the SE; it is about $15 \mathrm{~km}$ long, $2 \mathrm{~km}$ wide, and up to $750 \mathrm{~m}$ thick. The ophiolite forms slopping and narrow lowland separating the steep anticlinal mountain of Vourinos marbles in the west, from the calcareous hills of Rhodiani at the east.

The tectonic and petrogenetic relation between the Rhodiani ophiolite and the Vourinos complex is unclear; both are part of the Jurassic "Tethyan" ophiolite system and have been exploited for chrome. In the Rhodiani area about 60.000 tons of massive ore were produced (Economou et al. 1986).

The ophiolitic complex has been considered, on the whole, as a unique tectonic unit thrust on the metamorphic Triassic-Jurassic platform of the area and its overlain by single and simplified Upper Jurassic to Upper Cretaceous limestone cover with flysch (Brunn, 1956; Moores, 1969; Zimmerman, 1972; Mavridis \& Kelepertzis, 1993).

In this study, based on a detailed geological mapping, the tectono-stratigraphy of the ophiolite complex and of the overlying carbonate cover are re-evaluated.

\section{TECTONO-STRATIGRAPHIC SETTING}

The following units have been recognised from bottom to top:

-The para-autochthonous unit, which consists of Triassic - Jurassic marbles, overlain by a volcano-sedimentary mulange;

-The ultramafic unit and the overlying Cretaceous sedimentary cover; and

-The volcanic unit and the overlying Jurassic - Cretaceous limestone formation with flysch deposits.

1. Institute of Geology and Mineral Exploration, 11527 Athens, GREECE.

2. University of Athens, Department of Geology, 15784 Athens, GREECE. 


\subsection{PARA-AUTOCHTHONOUS UNIT}

This unit consists of a thick (200 - $600 \mathrm{~m})$ metamorphic carbonate series of fine-grained marble and dolomite intercalation of Triassic to Jurassic age (Brunn, 1956; Mercier, 1968; Mavridis \& Matarangas, 1979; Papanikolaou \& Zambetakis-Lekkas, 1980; Mavridis \& Kelepertzis, 1993). Towards the top, they become thinbedded and bear silex nodules, and are overlain by a mılange formation. The marbles exhibit characteristic isoclinal and recumbent folds of long length with flow schistosity. From base to top the mulange consists of a metaclastic sequence bearing strongly deformed red cherts, mudstones, shales, siltstones and schists, including olistholites of schistose metabasalts, rodingites, and serpentinised-schistose ultramafics with blocks of marble and amphibolite bodies. This assemblage is analogous to the Aghios Nikolaos formation found at the base of Vourinos ophiolite complex (Naylor \& Harle, 1976; Vergely, 1977; 1984;).

This basal unit belongs to the Triassic - Jurassic Pelagonian platform, having on its top a volcano-sedimentary milange, and it is considered to belong to the amphibolite to greenschist facies metamorphism that took place during the Upper Jurassic times and prior to the ophiolite emplacement (Mercier, 1968; Mountrakis, 1984).

On that basement, which is exposed mainly at the western part of the study area (eastern Vourinos foothill), an ultramafic ophiolite unit is in tectonic contact.

\subsection{ULTRAMAFIC UNIT (MIDDLE UNIT)}

This unit, up to $600 \mathrm{~m}$ thick, is generally composed of ultramafic rocks, and locally covered by meso-autochthonous Cretaceous sediments; it is overthrust on the mulange and the marble of the para-autochthonous unit. Additionally, the ultramafic unit represents part of an important ophiolite nappe that is exposed in the whole Pelagonian domain and, is also found between Pindos, Vourinos and Vermion. Furthermore, the dating of amphibolites from the base of Vourinos ophiolite complex indicates the Middle Jurassic age of its emplacement (Spray \& Roddick, 1980; Spray et al., 1984).

Small amphibolite blocks are also sporadically wedged at the basal part of the unit, and serpentinised, banded ultramafic mylonites are observed immediately above the tectonic contact with the marble. They contain a tectonic fabric that parallels the underlying mulange.

The ultramafic unit consists of deformed and serpentinised mantle tectonite restite (depleted mantle harzburgite) and dunite as small pods and layers including abundant chromitite, and harzburgite intruded by equally deformed pyroxenite, gabbro and rodingitized dykes.

At the southern part of the area (Kastro locality, Fig. 2), the harzburgites and dunites contain a strong planar foliation defined by the alignment of orthopyroxene and spinel crystals, which elongate and define a lineation within the plane of the foliation.

Mantle tectonic studies of this ultramafic part show that high-temperature mantle fabrics trend NW and dip at approximately $40^{\circ}$ towards the SW. Parallel mylonite zones accompany these fabrics; also thrust displacement towards the present NE has occurred. These fabrics are also parallel to the thrust planes, where chromitite bodies are included in the dunite masses. These high-temperature fabrics are significant because they probably represent structures during initial ductile thrusting.

The Vourinos high-temperature foliation is extremely comparable with the study area ( $50^{\circ}$ to the $\mathrm{SW}$ ), suggesting that the foliation in these peridotites was fossilized at high-temperature during the initial detachment

Fig.1: Geological map of Vourinos ophiolitic complex in relation to the Rhodiani area (Moores, 1969; Zimmerman, 1972) modified (A); geological map of the Rhodiani area (B) with its interpretative tectonostratigraphic column (C) and geological cross-sections $X-X, Y-Y^{\prime} \& Z-Z^{\prime}(D)$.

A: (1) Triassic - Jurassic carbonates (Pelagonian marbles); (2) tectonic milange; (3) dunites and harzburgites; (4) gabbros and diorites; (5) effusive and hypabyssal rocks; (6) Upper Jurassic to Upper Cretaceous limestone. B, C \& D: (1) Pelagonian marbles; (2) volcano-sedimentary milange; (3) ultramafic tectonic unit; (3a) serpentinised and banded ultramafic mylonites; ( $3 b$ ) mainly harzburgites and dunites; (3c) brecciated dunite;

(3d) chromitite pods; (4) Albian - Cenomanian calcarenite; (5) volcanic tectonic unit; (5a) sheeted dolerite complex; (b) pillow lava with boninitic dyke and red chert; (6) Upper Jurassic limestone; ( $\beta$ ) bauxite horizon; (7)

Upper Cretaceous limestone; (7a) conglomerate limestone; (7b) neritic and debris flow limestones; (7c) pelagic limestone; (8) Upper Maastrichtian flysch; (9) molasse formation; (10a) Neogene and Quaternary deposits; (10b) Quaternary talus cone and scree; $(\Phi)$ thrust; (d) detachment fault; (f) fault. 


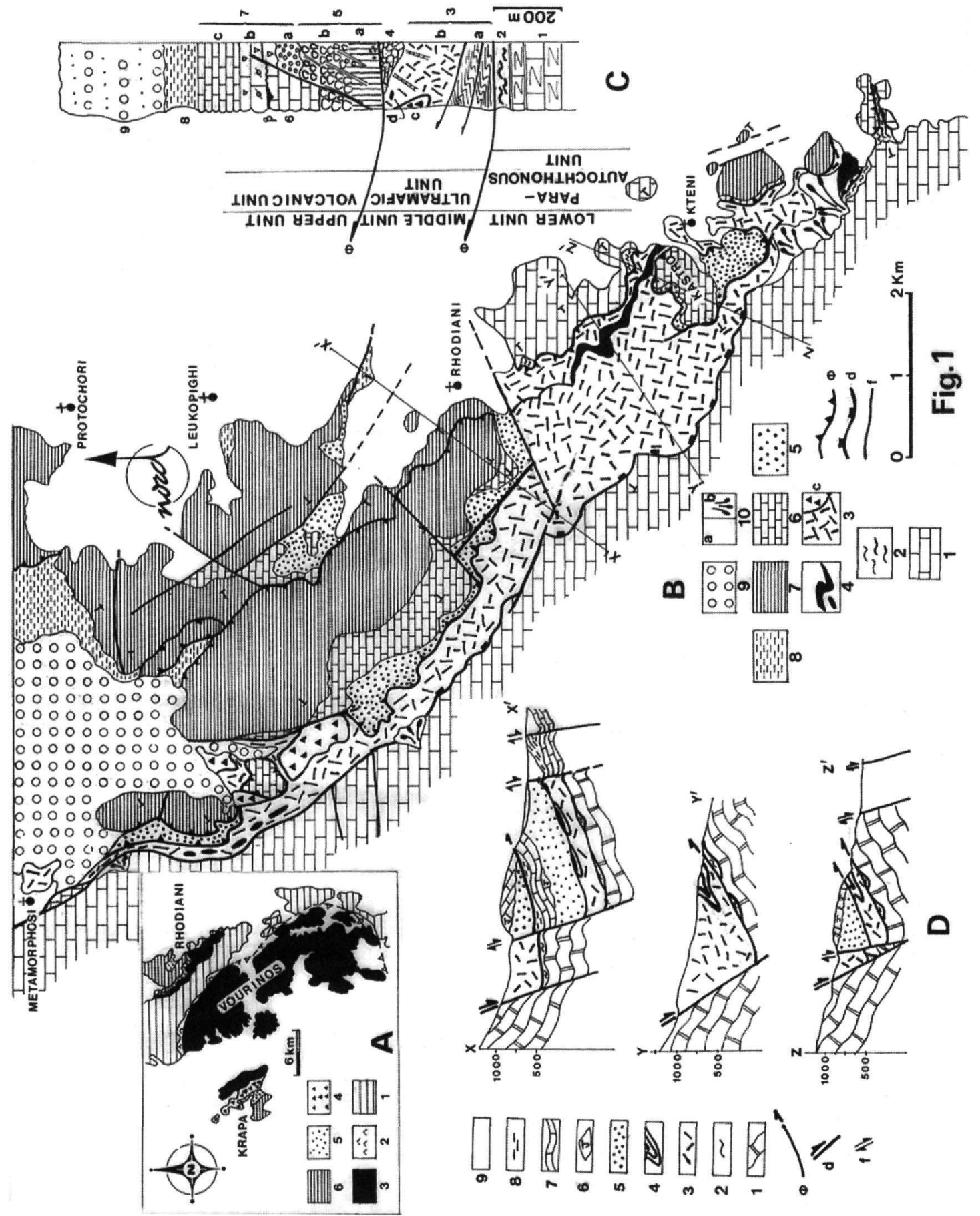




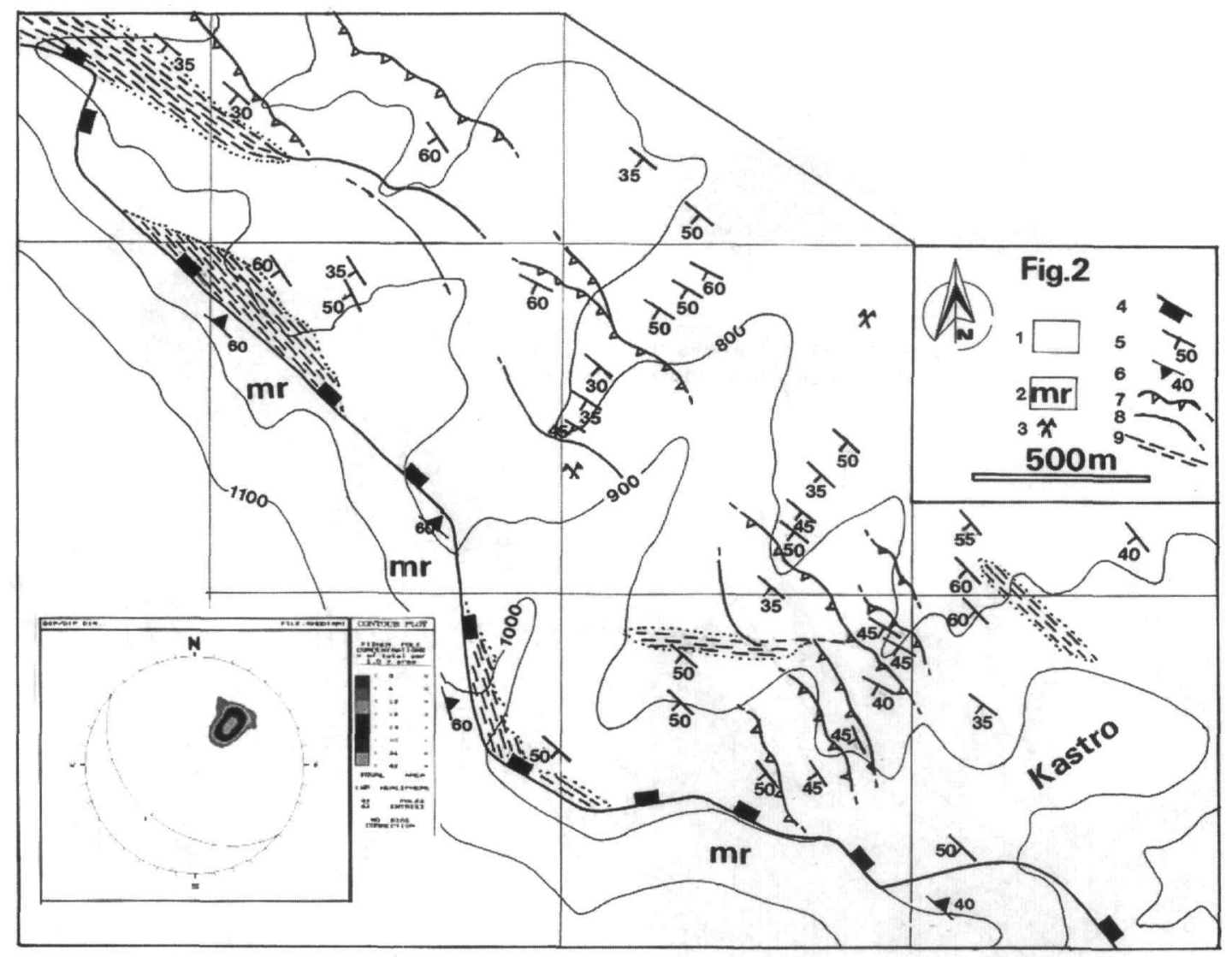

Fig. 2: Tectonic structures within the southern part of the ultramafic unit (Kastro locallity) and stereonet, equal area/lower hemisphere, of high-temperature fabrics $(N=43)$. 1: harzburgite and dunite; 2: marble; 3: chromite mine; 4: tectonic contact (detachment); 5: high-temperature mineral foliation (strike with dip); 6:strike with dip in marble; 7: mylonite zone; 8:brittle shear; 9: cataclastic zone.

and obduction of the peridotite towards the NE (Roberts et al., 1988; Grivas et al., 1993). However, the position of the Rhodiani ultramafic unit appears to be originally controlled by the Jurassic emplacement movement of the northern Vourinos ophiolite complex. Therefore, the Rhodiani ultramafic unit is interpreted as an eastward continuation of the Vourinos ophiolite complex.

On that ultramafic basement, in some localities (e.g. Kteni village, see Fig.1) an Albian-Cenomanian age cover, up to $50 \mathrm{~m}$ thick, is preserved. The base of the section consists of thick-bedded shallow-water grainstone limestone and towards the top, thin-bedded redeposited calcirudite and calcarenite limestones with ultramafic detritus.

This sequence shows good turbiditic structures and consists mainly of hemipelagic sediments, and contains Cuneolina pavonia, Praechrysalidina infracretacea and Salpingoporella hasi (determinations after Dr. V. SkourtsisCoroneou, 1993-97 and Dr. N. Carras, 1998). It was derived almost entirely from shallow-marine shelf-type source (ophiolite and limestone). It appears to have resulted from significant tectonic event affecting the source area.

Elsewhere the ultramafic unit, as at the northwest narrow area consists of deformed serpentinites bearing dunite bodies, rodingitized gabbro dykes folded along sub-horizontal axes, coarse-grained isotropic gabbro, as boudins and various tectonic slices of tightly folded Cretaceous limestones dipping NE (Fig.1). The presence of mylonites and various ophiolitic boudins along the tectonic contact reveals a semi-ductile extensional tectonic fabrics (detachment fault; Fig.1 see D)). This deformation is probably associated with impressive extensional phase which affected the Vourinos ophiolites simultaneously with the Meso-Hellenic trough creation during Oligocene times (Mountrakis et al., 1993).

However, this tectonic event was also responsible for the large scale normal faults trending NW-SE and dipping NE in the area, in brittle conditions. 


\subsection{VOLCANIC UNIT (UPPER UNIT)}

In the eastern parts of the massif, a crustal sequence with intrusive and extrusive rocks, up to $150 \mathrm{~m}$ thick, is exposed (Fig.1). It overlies tectonically the previous ultramafic unit with its carbonate cover, overlying a postEocene thrust fault. Perhaps this thrust fault is also reactivated during the subsequent Oligocene extensional phase. It is marked by the presence of dunite bodies, isotropic gabbros, rodingites, diorites, amphibolite and dolerite boudins. Although tectonized, the volcanic unit preserves many original igneous contact relationships, and therefore it represents a typical oceanic crust.

The base of this volcanic unit consists of coarse-grained sheeted dolerite dykes (individually up to $2 \mathrm{~m}$ thick) including at its deepest part rare fine-grained gabbro screens. The transition upwards into volcanic sequence demonstrated by the appearance of screens of pillowed and massive basalts. Towards the top, porphyritic (boninite) dykes crosscut the microphyric to vesicular pillow-lava flow sequence. Epidote is common, either as vein mineral or filling vesicles. Near to Leucopighi, sheeted dykes pass locally upwards into boninitic pillow lavas. The presence of boninitic dykes has also been provided evidence of their late-stage intrusion. Finally, the pillow-lava is overlain locally by red cherts. In general, this unit has experienced intense hydrothermal metamorphism within the oceanic environment. All the volcanic products display lower to upper greenschist facies oceanic metamorphism.

The crustal sequence overlain by an upper Pelagonian sedimentary sequence composed from the bottom to the top, of a Middle Jurassic crystalline and coral limestone bearing Lohmaeosmilia WELLS, an Upper Jurassic limestone with Clypeina jurassica and Macroporella Selli, locally bauxite deposits, a Lower Cretaceous limestone with Orbitolina Conoidea, various Turonian conglomerate and debris flow limestones and finally an Upper Cretaceous pelagic limestone, followed by Upper Maastrichtian flysch deposition (Brunn, 1956; Faug日res \& Robert, 1969; Brunn et al., 1972; Pichon, 1977; Mavridis \& Kelepertzis, 1993; Bortolotti et al., 2000).

In several places, the crustal sequence has been partially eroded up to the level of sheeted dykes, and has been overlain by a basal conglomerate and debris flow limestone of Turonian transgression followed by an Upper Cretaceous pelagic limestone and flysch deposit.

This sequence can be correlated with that of the upper part of the western Vourinos ophiolite complex, where in the Krapa Hills the Upper Jurassic limestone is pelagic, and presents a slightly unconformable Cretaceous limestone (Pichon, 1977; Paupy, 1976; Pichon \& Lys, 1976; Mavrides et al., 1977; Beccaluva et al., 1984; Rassios et al., 1983).

Post-orogenic Tertiary conglomerates, that was named by Brunn (1956) as Metamorphosis conglomerates (see Fig.1), consist of molasse sediments of fluvial origin, which overlie unconformably the northwestern part of the study area. They consist of debris from all formations suggesting an active erosional phase due to the Tertiary post-orogenic collapse (Doutsos et al., 1994), and deposited after the Aquitanien.

\section{DISCUSSION-CONCLUSIONS}

Previous studies carried out in the Rhodiani area by Brunn (1956), Moores (1969), Zimmerman (1972), Mavridis \& Kelepertzis (1993), described a single and simplified ophiolite tectonic unit overlain by a unique Upper Jurassic to Upper Cretaceous limestone cover. This study however suggests that the ophiolite outcrop consists of an imbricated ophiolite structure, which is composed of two tectonic ophiolite units associated with their limestone cover; the tectonic stacking order is related with the significant orogenic phases, which affected the internal Hellenides.

The ophiolite was overthrust onto the mulange of the Triassic - Jurassic platform during a late Jurassic plate convergence at the Eohellenic orogeny (Jacobshagen et al., 1978). Following this, the ultramafic and volcanic units developed neritic and deep-water carbonate deposits during Late Jurassic to Late Cretaceous.

The Rhodiani ophiolite appears to be an eastward thinning slab of the same oceanic and mantle sections as the Vourinos ophiolite supra-subduction zone (Beccaluva et al., 1984) following deformation due to the northeastern emplacement process on the Pelagonian margin. Therefore, the position of ultramafic unit of Rhodiani area appears to be originally controlled by the Jurassic emplacement movement of the Vourinos ophiolite (Roberts et al., 1988; Grivas et al., 1993). During this process, the Rhodiani massif has been dismembered as ultramafic and volcanic units and attained an increasingly imbricated ophiolite structure compared to the Vourinos ophiolite complex. Following, the transgressive Jurassic - Cretaceous carbonate cover was deposited.

Furthermore, during the post-obduction Upper Jurassic - Lower Cretaceous period, some parts of the ultramafic tectonic unit and the faulted carbonate platform were exposed and eroded and then materials from both of these sources were fed into a basin composing the overlying turbiditic calcarenite sequence of Albian Cenomanian age. 
During the same post-obduction period, the wider Pelagonian domain was not affected by the same environmental conditions; in the western Vermion the ultramafic thrust sheet, was suffered by exogenous conditions and laterization process (Photiades et al., 1998), the Rhodiani volcanic ophiolitic unit developed bauxite deposits within the post-Upper Jurassic shallow water carbonate cover (Bortolotti et al., 2000), and finally the Rhodiani ultramafic unit followed upwards by a flysch-type sequence of Albian - Cenomanian age, like a flysch-type sequence of Berriasian age intercalated between Pindos Eocene flysch and Pindos ophiolite thrust sheets (Terry \& Mercier, 1971).

During the Lower Cretaceous, ophiolitic basement was most probably still partly submerged and it was affected by a significant tectonic event. This event is probably of Berriasian age, and therefore correlates to the Late Jurassic to Early Cretaceous deformation of the eastern margin of the Pelagonian continent (phase J2b of Vergely, 1984).

Finally, during Late Cretaceous the platform and slope carbonates are separated from the Late Cretaceous basinal sediments, since they consist mainly of platform and slope-type carbonates and occupy a higher position within the thrust stack.

The final closure of the remaining Pindos basin occurred when the Pelagonian microplate collided with the Apulian one at early to middle Eocene time (Robertson et al., 1991). Subsequently, the Blueschist Unit that originated in the Pindos basin (Altherr et al., 1979; Bonneau, 1984) was thrust over a carbonate shelf of Apulia now exposed as tectonic metamorphic windows of the Kranea-Elassona, Olympus, Ossa and Almyropotamos units (Vergely \& Mercier, 1990). This post-Upper Eocene collisional phase is thought to have caused the thrusting of the internal Hellenides over the external Hellenides and induced the re-thrusting of the Rhodiani volcanic ophiolitic unit with Upper Jurassic - Cretaceous cover, overlying the ultramafic unit with Albian - Cenomanian redeposited limestone cover.

Finally, an extensional phase affected the Vourinos and the Rhodiani ophiolites simultaneously with the Meso-Hellenic trough creation during Oligocene times (Mountrakis et al., 1993), and then post-orogenic transgressive molasse deposits covered the thrust sheets to the east and to the west.

\section{REFERENCES}

ALTHERR, R., SCHLIESTEDT, M., OKRUSCH, M., SEIDEL, E., KRUEZER, H., HARRE, W., LENZ, H., WENDT, J. \& WAGNER, G.A. (1979): Geochronology of high-pressure rocks on Sifnos (Cyclades, Greece). Contrib. Mineral. Petrol., 70, 245-255.

BECCALUVA, L., OHNENSTETTER, D., OHNENSTETTER, M. \& PAUPY, A. (1984): Two magmatic series with island-arc affinity within the Vourinos ophiolite. Contrib. Mineral. Petrol., 85, 253-271.

BONNEAU, M. (1984): Correlation of the Hellenides nappes in southeast Aegean and their tectonic reconstruction. In: DIXON J.E. \& ROBERTSON, A.H.F. (Eds.) In: DIXON J.E. \& ROBERTSON, A.H.F. (Eds.) The geological evolution of the Eastern Mediterranean. Geol. Soc. London, Spec. Publ. 17,517-528.

BORTOLOTTI, V., CARRAS, N., CHIARI, M., FAZZUOLI, M., MARCUCCI, M., PHOTIADES, A. \& PRINCIPI, G. (2000): Decline and fall of an Upper Jurassic - Cretaceous carbonate platform, born (possibly) over wedging ophiolites: Vourinos- Pindos area, Northern Greece- Preliminary results. Abstract and Poster for the $80^{a}$ Riunione estiva della Soc. Geol. Italiana, Trieste, 6-8 Setembre 2000, 93p.

BRUNN, (1956): Etude géologique du Pinde septentrional et de la Macédoine occidentale. Ann. géol. Pays Hellén., 7, 358p.

BRUNN, J.H., FAUGERES, L. \& ROBERT, P. (1972): Une nouvelle série du Jurassique moyen - Crétacé inférieur surmontant les ophiolites dans le détroit de Kozani (Macédoine, Grèce). C. R. somm. Soc. géol. France, 1, 2627.

DOUTSOS, T., KOUKOUVELAS, I., ZELILIDIS, A. \& KONTOPOULOS, N. (1994): Intracontinental wedging and post-orogenic collapse in the Mesohellenic trough. Geol. Rundsch. 83, 257-275.

ECONOMOU, M., DIMOU, E., ECONOMOU, G., MIGIROS, G., VACONDIOS, J., GRIVAS, E., RASSIOS, A. \& DABITZIAS, S. (1986): Chromite deposits of Greece. Theophrastus publications S.A., Athens, 129-159.

FAUGERES, L. \& ROBERT, P. (1969): Précisions nouvelles sur les altérations contenues dans la série du chaînon de Vigla (Kozani, Macédoine, Grèce). C. R. somm. Soc. géol. France, 97-98.

GRIVAS, E., RASSIOS, A., KONSTANTOPOULOU, G., VACONDIOS, I. \& VRAHATIS, G. (1993): Drilling for "blind" podiform chrome ore bodies at Voidolakkos in the Vourinos ophiolite complex, Greece. Econ. Geol., 88, 461-468.

JACOBSHAGEN, V., DURR, ST., KOCKEL, F., KOPP, K.O. \& KOWALCZYK, G. (1978): Structure and geodynamic evolution of the Aegean region. In Cloos, Roeder and Schmidt (eds.), Alps, Apennines, Hellenides, 
Scheizerbart'sche Vergagsbuchhandlung, Stuttgart, 537-564.

JONES, G. \& ROBERTSON, A.H.F. (1991): Tectono-stratigraphy and evolution of the Mesozoic Pindos ophiolite and related units, northwestern Greece. J. Geol. Soc. London, 148, 267-288.

NAYLOR, M.A. \& HARLE, T.J. (1976): Paleogeographic significance of rocks and structures beneath the Vourinos ophiolite Northern Greece. J. Geol. Soc. London, 132, 667-675.

MAVRIDIS, A. \& KELEPERTZIS, A. (1993): Geological map of Greece «KNIDHI sheet» in scale 1:50.000. $\operatorname{IGME}($ Ed.), Athens, Greece.

MAVRIDIS, A. \& MATARANGAS, D. (1979): Geological map of Greece «AYIOFILLON sheet» in scale 1:50.000. $\operatorname{IGME}(E d$.$) , Athens, Greece.$

MAVRIDES, A., SKOURTSIS-KORONEOU, V. \& TSAILA-MONOPOLIS, S. (1977): Contribution to the geology of the Subpelagonian Zone (Vourinos area, West Macedonia): In $6^{\text {th }}$ Colloquium on the Geology of the Aegean Region. IGME, Athens, 175-195.

MERCIER, J. (1968): Etude géologique des zones internes des Hellénides en Macédoine centrale (Grèce). Ann. géol. Pays Hellén., 20, 1-792.

MOORES, E.G. (1969): Petrology and structure of the Vourinos ophiolite complex of Northern Greece. Geol. Soc. Am., Spec. Paper, 118, 74pp.

MOUNTRAKIS, D. (1984): Structural evolution of the Pelagonian zone in Northwestern Macedonia, Greece. In: DIXON J.E. \& ROBERTSON, A.H.F. (Eds.) In: DIXON J.E. \& ROBERTSON, A.H.F. (Eds.) The geological evolution of the Eastern Mediterranean. Geol. Soc. London, Spec. Publ. 17, 581-590.

MOUNTRAKIS, D., KILIAS, A. \& ZOUROS, N. (1993): Kinematic analysis and Tertiary evolution of the Pindos - Vourinos ophiolites (Epirus - Western Macedonia, Greece). Bull. Geol. Soc. Greece, 28/1, 111-124.

PAPANIKOLAOU, D. \& ZAMBETAKIS-LEKKAS, A. (1980): Nouvelles observations et datation de la base de la série pélagonienne (s.s.) dans la région de Kastoria, Grèce. C. R. Acad. Paris, 291, 155-158.

PAUPY, (1976): Nouvelles données sur un type de différenciation du magma ophiolitique: Le Massif du Vourinos (Grèce).Thèse Université de Nancy, 182p.

PHOTIADES, A., SKOURTSIS-CORONEOU, V. \& GRIGORIS, P. (1998): The stratigraphic and paleogeographic evolution of the eastern Pelagonian margin during the Late Jurassic - Cretaceous interval (Western Vermion Mountain - Western Macedonia, Greece). Bull. Geol. Soc. Greece, 32/1, 71-77.

PICHON, (1977): Une transversale dans la Zone Pélagonienne, depuis les collines de Krapa (SW) jusqu'au massif du Vermion (NE): Les premières séries transgressives sur les ophiolites): In $6^{\text {th }}$ Colloquium on the Geology of the Aegean Region. IGME, Athens, 163-171.

PICHON, J.F. \& LYS, M. (1976). Sur l'existence d'une série du Jurassique supérieur à Crétacé inférieur surmontant les ophiolites dans les collines de Krapa (Massif du Vourinos, Grèce). C. R. Acad. Sci., Paris, 282, 523-526.

RASSIOS, A., BECCALUVA, L., BORTOLOTTI, V., MAVRIDES, A. \& MOORES, E. (1983): Vourinos complex: Field guide for workshop on the Vourinos-Guevgueli ophiolites, I.G.C.P. 197. Ofioliti, 8/3, 275-292.

ROBERTS, S., RASSIOS, A., WRIGHT, L., VACONDIOS, I., VRACHATIS, G., GRIVAS, E. \& NESBITT, R. (1988): Structural controls on the location and form of the Vourinos chromite deposits. In Boissonas, J. \& Omenetto, P. (eds.), Mineral deposits within the European Community, Soc. Geol. Appl. Min. Deposits, Spec. Publ., 6, 249-266.

ROBERTSON, A.H.F., CLIFT, P.D., DEGNAN, P.J. \& JONES, G. (1991): Palaeogeographic and palaeotectonic evolution of the eastern Mediterranean Neotethys. Palaeo. Palaeo. Palaeo., 87, 289-343.

VERGELY, P. (1977): Discussion of the paleogeographic significance of rocks beneath the Vourinos ophiolite, northern Greece. J. Geol. Soc. London, 133, 505-507.

VERGELY, P. (1984): Tectonique des ophiolites dans les Hellénides internes. Conséquences sur l'évolution des régions téthysiennes occidentales. Thèse d'Etat Sc. Naturelles, Univ. Paris-Sud, 649p., Orsay.

VERGELY, P. \& MERCIER, J. (1990): La fenêtre métamorphique de l'Olympe (Macédoine, Grèce); Compression et extension cénozoïques. Bull.Soc.géol.France, 6/5, 819-829.

SMITH, A.G., WOODCOCK, N.H. \& NAYLOR, M.A. (1979): The structural evolution of a Mesozoic continental margin, Othris Mountains, Greece. J. Geol. Soc. London, 136, 589-603.

SPRAY, J.G., BEBIEN, J., REX, D.C. \& RODDICK, J.C. (1984): Age constraints on the igneous and metamorphic evolution of the Hellenic-Dinaric ophiolites. In: DIXON J.E. \& ROBERTSON, A.H.F. (Eds.) The geological evolution of the Eastern Mediterranean. Geol. Soc. London, Spec. Publ. 17, 619-627.

SPRAY, J.G. \& RODDICK, J.C. (1980): Petrology and 40Ar/39Ar geochronology of some Hellenic sub-ophiolite metamorphic rocks. Contrib. Mineral. Petrol., 72, 43-55.

TERRY, J.P. \& MERCIER, M. (1971): Sur l'existence d'une série détritique berriasienne intercalée entre la nappe 
des ophiolites et le flysch Éocène de la nappe du Pinde (Pinde septentrional, Grèce). C. R. somm. Soc. géol. France, 71-73.

ZIMMERMAN, J.Jr. (1972): Emplacement of Vourinos ophiolite complex, Northern Greece. Geol. Soc. Am. Mem. 132, 225-239. 